\title{
Quaternary climate change and Heinrich events in the southern Balkans: Lake Prespa diatom palaeolimnology from the last interglacial to present
}

\author{
Aleksandra Cvetkoska $\cdot$ Zlatko Levkov • Jane M. Reed • \\ Bernd Wagner $\cdot$ Konstantinos Panagiotopoulos $\cdot$ \\ Melanie J. Leng • Jack H. Lacey
}

Received: 17 June 2014/Accepted: 2 December 2014/Published online: 11 December 2014

(C) Springer Science+Business Media Dordrecht 2014

\begin{abstract}
Lake Prespa, in the Balkans, contains an important palaeo-archive in a key location for understanding Quaternary climate variability in the transition between Mediterranean and central European climate zones. Previous palaeoenvironmental research on sediment cores indicates that the lake is highly sensitive to climate change and that diatoms are likely to be strong palaeohydrological proxies. Here, we present new results from diatom analysis of a ca. $91 \mathrm{ka}$ sequence, core Co1215, which spans the time from the end of the last interglacial to the present. Fluctuations in the diatom data were driven primarily by changes in lake level, as a function of shifts in moisture availability. Warmer interglacial (MIS 5, MIS 1) and interstadial (MIS 3) phases exhibit higher lake levels in spite of enhanced evaporative concentration, underlining the
\end{abstract}

A. Cvetkoska $(\bowtie) \cdot$ Z. Levkov

Faculty of Natural Sciences, Institute of Biology, Ss Cyril and Methodius University, Arhimedova 3, 1000 Skopje,

Republic of Macedonia

e-mail: acvetkoska@yahoo.com

\section{J. M. Reed}

Department of Geography, Environment and Earth

Sciences, University of Hull, Hull, UK

B. Wagner

Institute of Geology and Mineralogy, University of

Cologne, Cologne, Germany

K. Panagiotopoulos

Seminar of Geography and Education, University of

Cologne, Cologne, Germany importance of changes in precipitation regimes over time. Low lake levels during glacial phases indicate extreme aridity, common to all Mediterranean lakes. Evidence for fluctuations in trophic status is linked, in part, to lake-level change, but also reflects nutrient enrichment from catchment processes. MIS 5a is characterized by the highest lake productivity in the sequence, but low lake levels, which are ascribed primarily to very low precipitation. On a suborbital timescale, the diatoms provide evidence for correlation to the millennial-scale variability recorded in the Greenland oxygen isotope records and clearly reflect the impact of the Heinrich H6, H5 and H3-1 ice-rafting events, suggesting the dominant influence of North Atlantic forcing in this region. Although the highestamplitude shift in the diatom assemblages occurs

\section{J. Leng}

Centre for Environmental Geochemistry, School of Geography, University of Nottingham, Nottingham, UK

M. J. Leng · J. H. Lacey

NERC Isotope Geosciences Facility, British Geological Survey, Nottingham, UK

J. H. Lacey

Department of Geology, University of Leicester, Leicester, UK 
during the time of $\mathrm{H} 4$ (40-38 ka), it may be superimposed upon the impact of the $39.28 \mathrm{cal}$ ka BP Campanian Ignimbrite volcanic eruption. Diatoms from Lake Prespa core Co1215 display the first strong evidence for the impact of Italian volcanic activity on lacustrine biota in this region. Results emphasize the complexity of diatom response thresholds in different studies across the region. In the case of Lake Prespa, the results highlight the important role of precipitation for maintaining the hydrological balance of the lake, and indirectly, its biodiversity.

Keywords Lake Prespa - Diatoms · Lake-level change $\cdot$ Palaeoclimate $\cdot$ Tephra impact $\cdot$ Quaternary Heinrich events

\section{Introduction}

Quaternary researchers in the last few decades have made considerable efforts to understand spatial climate variability in the Mediterranean, but the main underlying mechanisms are still under debate (Magny et al. 2012). This is partly because of gaps in our understanding of spatial and temporal variability. Of the various palaeolimnological indicators studied, diatoms, in most cases, have been restricted to the late Glacial and Holocene epoch (Wilson et al. 2008; Jones et al. 2013). Diatom palaeoclimate records spanning multiple glacial-interglacial transitions are still very rare across the Mediterranean (Ampel et al. 2008, 2010), but demonstrate high sensitivity to climate change. A prime example is the diatom record from ancient Lake Ohrid (Reed et al. 2010; Cvetkoska et al. 2012), in which diatoms provide strong evidence for the lake's response to climate variability since the penultimate glacial-interglacial transition to the present.

Lake Prespa, in the Balkans, is an ancient lake that likely co-existed with its neighbour Lake Ohrid for more than 1 Ma (Stankovic 1960). Preliminary borehole data, core logging and geochemical data from a 569-m-long sediment sequence recovered during the Scientific Collaboration on Past Speciation Conditions (SCOPSCO) drilling campaign, indicate that Lake Ohrid is $>1.2$ Ma old (Wagner et al. 2014a, b). The exact age of Lake Prespa is still uncertain. The importance of both lakes, Ohrid and Prespa, as palaeoenvironmental archives for Mediterranean Quaternary climate research has been well documented (Wagner et al. 2008a). Multi-proxy geochemical analysis of a 10.5-m sequence from the northwestern part of Prespa demonstrates glacial-interglacial variability over the last ca. 48 ka (Leng et al. 2010; Wagner et al. 2010). A 17.76-m sequence, Co1215, spans the last $\sim 91 \mathrm{ka}$ (Damaschke et al. 2013). Multiproxy analysis of the last glacial to Holocene sequence from $\sim 17 \mathrm{ka}$ to present in Co1215 (Aufgebauer et al. 2012; Wagner et al. 2012; Leng et al. 2013; Panagiotopoulos et al. 2013; Cvetkoska et al. 2014a) provides a useful interpretive tool for longer-term climate variability.

Here, we build on previous palynological and geochemical studies (Panagiotopoulos et al. 2014) of the longer sequence, using diatoms to infer hydrological and productivity shifts since Marine Isotope Stage (MIS) 5b to present. Diatoms of Lake Prespa are highly sensitive to lake-level variation and are important in elucidating hydrological variability (Cvetkoska et al. 2014a). Trends in the extended multi-proxy dataset are assessed to explore the links between limnological and catchment change. The diatominferred palaeoclimate data are compared to other Mediterranean and global records to improve understanding of the nature of glacial-interglacial climate variability in this region.

Site description

A detailed description of the geographical, physical and chemical properties of Lake Prespa is provided in Hollis and Stevenson (1997). Lake Prespa (Fig. 1), also known as Macro Prespa, Macedonia/Albania/Greece, is located at an altitude of $849 \mathrm{~m}$ a.s.l., has a surface area of $254 \mathrm{~km}^{2}$, a mean water depth of $\sim 14 \mathrm{~m}$, a maximum water depth of $\sim 48 \mathrm{~m}$ and a total volume of $3.6 \mathrm{~km}^{3}$ (Wagner et al. 2012). The water balance is controlled by inputs from river inflow, catchment runoff, direct precipitation, inflow from Lake Mikri Prespa and groundwater. Output is via surface evaporation, water abstraction for irrigation and subsurface outflow through the karstic aquifers of Galicica Mountain into Lake Ohrid (Matzinger et al. 2006). Climate in the catchment is described as Mediterranean in the southern part and continental in the northern part, with a sub-alpine character below $1,650 \mathrm{~m}$ in elevation and alpine character above (Krstić 2012). Mean 
Fig. 1 Topographic map of Lake Prespa showing lake catchment (blue line) and location of cores Co1215 (this study) and Co1204 recovered from Lake Prespa (Wagner et al. 2010). NASA Shuttle Radar Topographic Mission (SRTM) Data: Jarvis et al. 2008 (modified from Panagiotopoulos et al. 2013). (Color figure online)

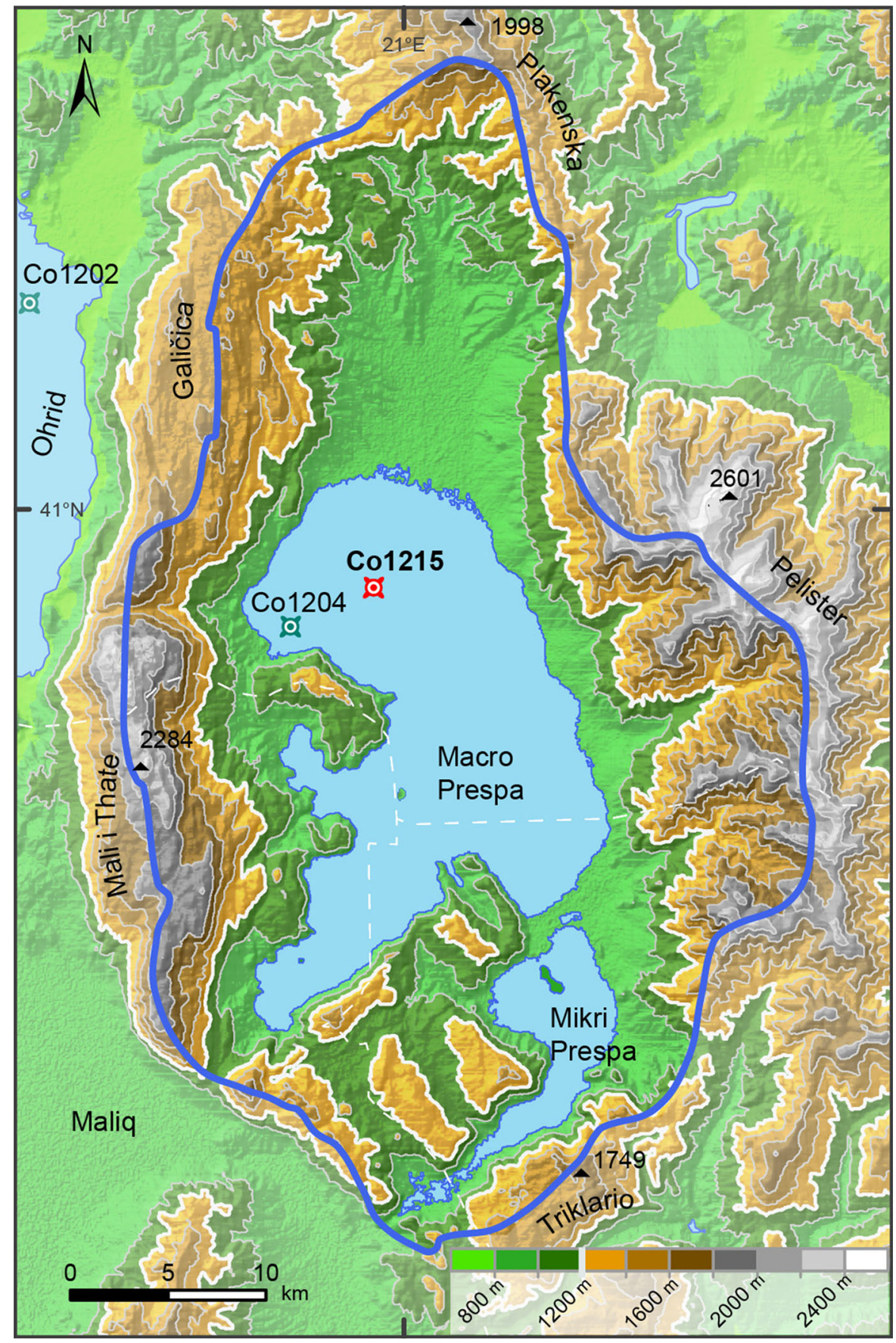

temperature fluctuates from $+1{ }^{\circ} \mathrm{C}$ in winter to $+21{ }^{\circ} \mathrm{C}$ in summer, and mean annual precipitation varies between 750 and $1,200 \mathrm{~mm} / \mathrm{a}$ in the lake valley and the surrounding mountain ranges, respectively (Hollis and Stevenson 1997).
Overall, the hydrology of Lake Prespa is controlled by a complex interplay of factors, including the geomorphology of the area, catchment vegetation, hydrology of the watershed area, climate, and its relatively large but shallow bathymetry, which lacks a 
surface outflow. This makes Lake Prespa highly sensitive to environmental forcing and especially susceptible to lake level change.

\section{Materials and methods}

Core Co1215 was recovered in the north-central part of Lake Prespa at a water depth of $14 \mathrm{~m}$, during two field campaigns, in November 2009 and June 2011 (Wagner et al. 2012; Damaschke et al. 2013). Coring was performed from a floating platform equipped with gravity corers for surface sediments and a 3-m-long percussion piston corer for deeper sediments (UWITEC Corp. Austria). Correlation of the individual core sections resulted in a 1,776-cm-long composite sequence.

Analytical core analysis, described in detail in Aufgebauer et al. (2012), Wagner et al. (2012), Leng et al. (2013) and Panagiotopoulos et al. (2014) consisted of non-destructive X-ray fluorescence (XRF) scanning, total carbon (TC) and total inorganic carbon (TIC) measurements, stable isotope ratios, $\mathrm{X}$-ray diffraction (XRD) mineralogy and palynological analysis. The final age-depth model for the sequence was presented in detail by Damaschke et al. (2013).

Diatoms were analyzed in 222 samples, taken at $\sim 8$-cm intervals (resolution $=\sim 0.1-0.4 \mathrm{ka}$ ), spanning the $1,760-\mathrm{cm}$ section, or the last $91.0 \mathrm{cal} \mathrm{ka}$. Samples were cleaned using cold $\mathrm{H}_{2} \mathrm{O}_{2}$ and $10 \% \mathrm{HCl}$ to oxidize organics and remove carbonates, respectively (Cvetkoska et al. 2012). Permanent diatom slides were prepared using Naphrax ${ }^{\circledR}$ as a mountant and $\sim 400$ diatom valves per slide (Battarbee 1986) were counted under oil immersion at $1,500 \times$ magnification using a Nikon Eclipse 80i microscope. Identification of diatom taxa followed Krammer and Lange-Bertalot (1986-1991) and the dedicated Ohrid and Prespa work of Levkov et al. (2007b) and Cvetkoska et al. (2012, 2014b). Diatom counts were converted to percentage data and displayed using Tilia and TGView v. 2.0.2. (Grimm 1991). Stratigraphic zone boundaries were defined using Constrained Incremental Sum of Squares cluster analysis (Grimm 1987) for diatom taxa present at $>2 \%$ abundance. Multi-proxy stratigraphic diagrams were prepared using C2 (Juggins 1991-2007). Correlation between diatom relative abundance data and geochemical proxies was tested using Spearman's rho correlation test, in the statistical package "stats," version 0.8-2 (R Core Team 2012). Variation in the diatom data was explored by ordination, and with a gradient length of $>2.5$, detrended correspondence analysis, ('DCA') was appropriate (Jongman et al. 1995).

\section{Results}

Core chronology

The core chronology (Fig. 2) was developed using accelerator mass spectrometry (AMS) ${ }^{14} \mathrm{C}$ dating, tephra analysis, electron spin resonance (ESR) and correlation with NGRIP ice core data (Damaschke et al. 2013). Calibration of the radiocarbon ages to calendar years (cal ka BP) was accomplished using the INTCAL09 calibration curve (Reimer et al. 2009), except for the uppermost sample, which was calibrated using the Levin ${ }^{14} \mathrm{C}$ dataset (Levin and Kromer 2004). At a core depth of 1,463-1,458 cm, a layer of shells of the mollusk Dreissena was dated by electron spin resonance (ESR) and was discussed in Damaschke et al. (2013) and Wagner et al. (2014c). Ages presented here are calendar years before present (cal ka BP) with $2 \sigma$ ranges. The detailed tephrostratigraphic record and sedimentation rates for the $1,776-\mathrm{cm}$ composite sequence are presented in Damaschke et al. (2013). The calculated sediment accumulation rate $(\mathrm{mm} / \mathrm{a}$; SAR) is between 0.09 and $1.36 \mathrm{~mm} / \mathrm{a}$, with the exception of a peak of $190 \mathrm{~mm} / \mathrm{a}$ at the time of deposition of tephra PT0915-7, correlated to the Campanian Ignimbrite (CI) eruption from the Campi Flegrei volcanic field (Damaschke et al. 2013).

\section{Diatom analysis}

Two hundred and seventy diatom taxa were identified in Lake Prespa core Co1215 and the summary diatom diagram (Fig. 3) displays the 40 taxa present at $>2 \%$ relative abundance. Six major diatom assemblage zones (D1-6), each divided into 2-4 subzones, were identified with CONISS. The DCA results (Fig. 4; Table 1) clearly support the stratigraphic zone delineation. Planktonic taxa, i.e. the Cyclotella complex and Aulacoseira spp., have high scores on Axis 1 (eigenvalue $=0.47$ ), and benthic taxa have low 
Fig. 2 Age-depth model with sediment accumulation rate, SAR $(\mathrm{mm} / \mathrm{a})$ of the composite core Co1215 from Lake Prespa (modified from Damaschke et al. 2013)
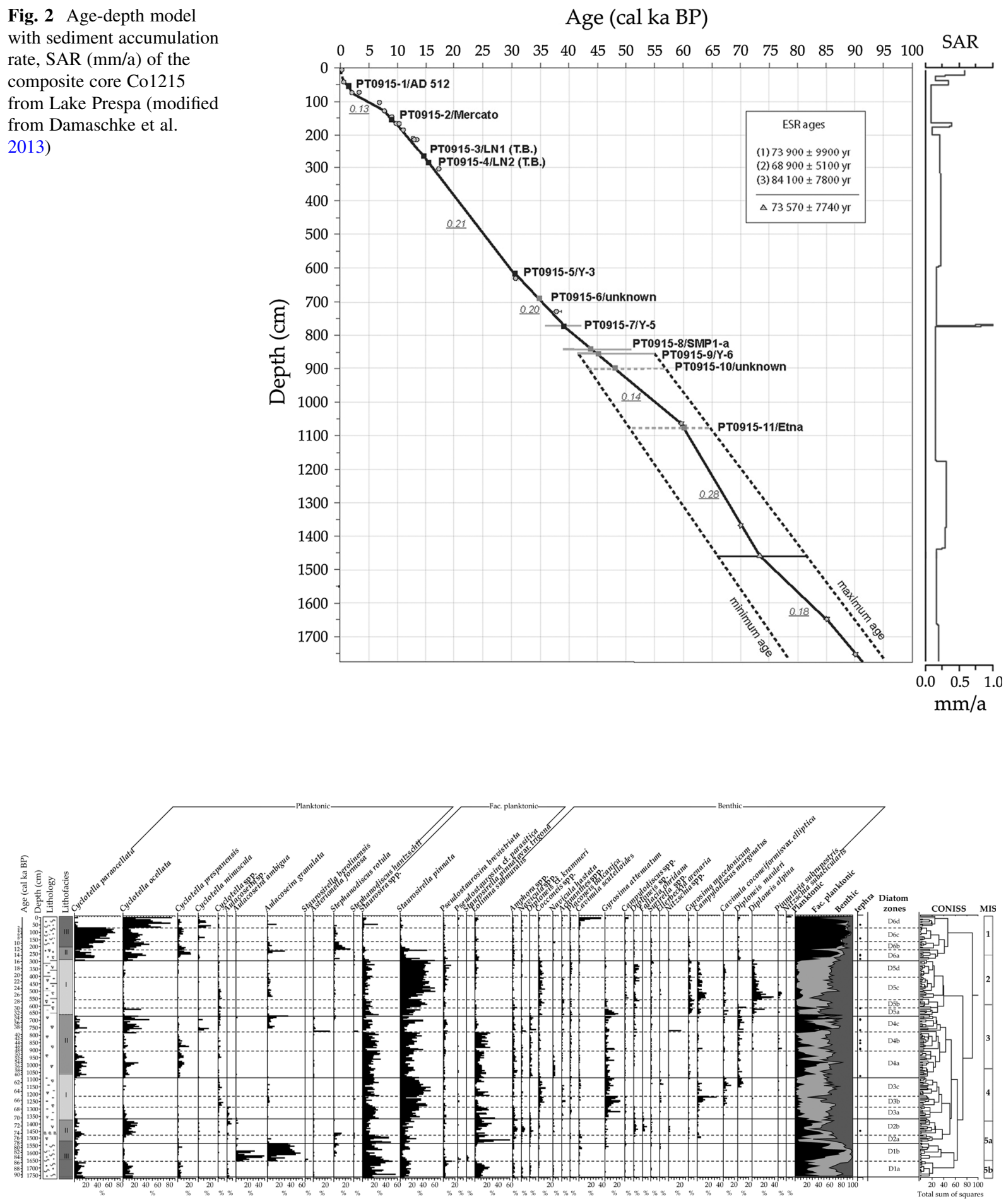

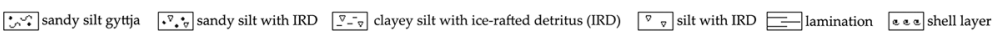

Fig. 3 Stratigraphic diagram of diatom taxa present at $>2 \%$ abundance in Lake Prespa core Co1215, displaying diatom zones defined by CONISS, lithology and lithofacies (modified from Damaschke et al. 2013). IRD = Ice-rafted debris, MIS = Marine Isotope Stage. MIS boundaries are from Lisiecki and Raymo (2005) 
Fig. 4 Scatter plot of DCA Axis 1 versus DCA Axis 2 scores of diatom samples and species from core Co1215. The symbol key in the top right hand corner represents the diatom zones. Diatom zone D1 is split into two subzones because of the marked difference in Axis 2 scores. Only selected diatom taxa are displayed

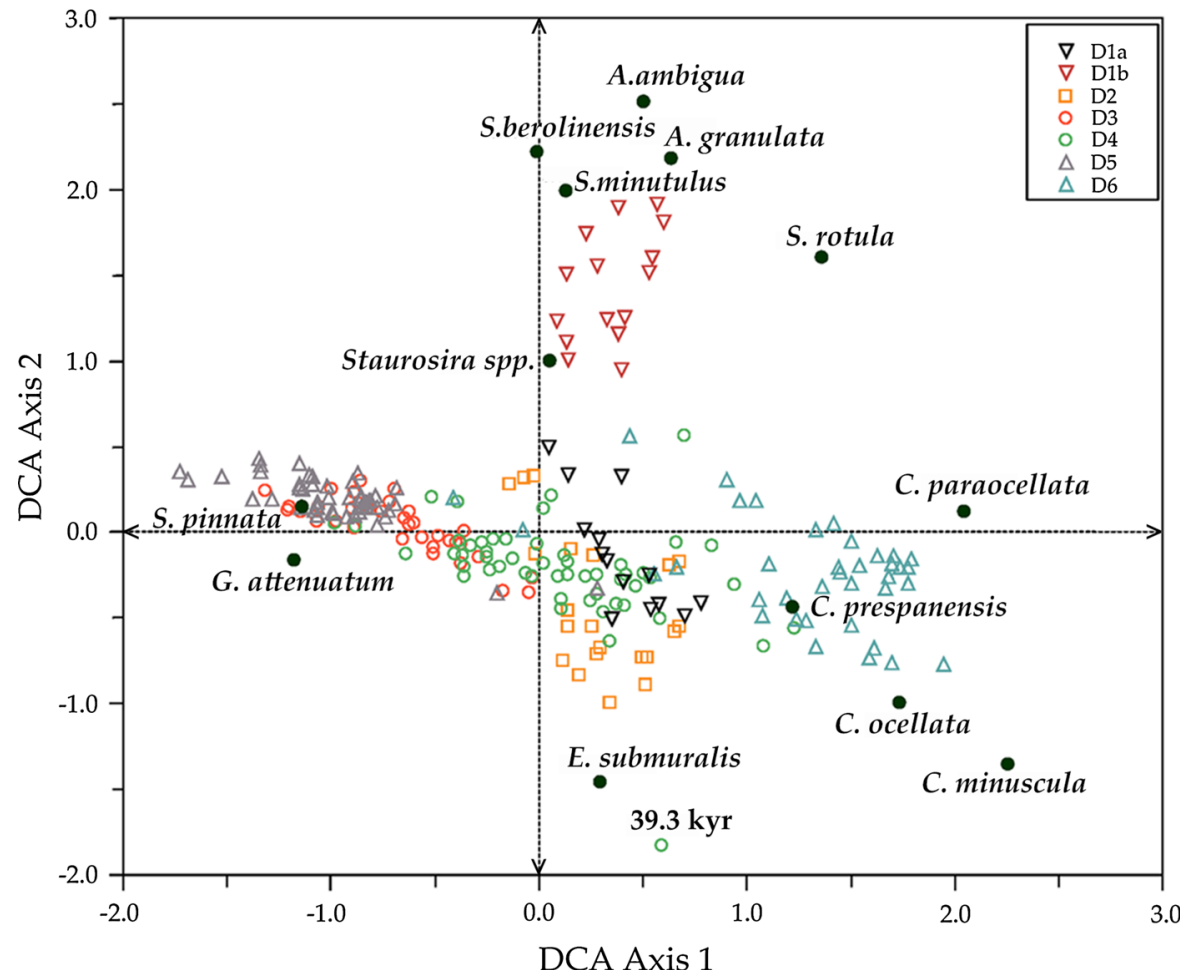

Table 1 Summary of the DCA ordination of the diatom assemblages found in Lake Prespa core Co1215 (222 samples) and Spearman's rho $(\rho)$ coefficient values for the correlations between selected diatom data and geochemical proxies and DCA score

\begin{tabular}{|c|c|c|c|c|c|}
\hline Axes & DCA 1 & DCA 2 & \multicolumn{2}{|c|}{ DCA 3} & DCA 4 \\
\hline Eigenvalues & 0.47 & 0.23 & \multicolumn{2}{|c|}{0.17} & 0.14 \\
\hline Axis lengths & 3.48 & 2.95 & \multicolumn{2}{|c|}{2.10} & 1.75 \\
\hline Decorana values & 0.50 & 0.32 & \multicolumn{2}{|c|}{0.12} & 0.08 \\
\hline Spearman's correlation & Cyclotella group & Fac. Plankton & S. pinnata & Benthic & E. submuralis \\
\hline TOC (\%) & 0.63 & -0.49 & -0.76 & -0.62 & 0.11 \\
\hline $\mathrm{TN}(\%)$ & 0.62 & -0.54 & -0.77 & -0.63 & -0.06 \\
\hline TOC/TN & 0.52 & -0.38 & -0.66 & -0.53 & 0.16 \\
\hline $\mathrm{Ca}$ (counts) & l & l & -0.53 & -0.38 & -0.05 \\
\hline K (counts) & -0.63 & 0.54 & 0.69 & 0.63 & 0.14 \\
\hline Ti (counts) & -0.57 & 0.55 & 0.64 & 0.56 & 0.20 \\
\hline $\mathrm{Fe} / \mathrm{Ti}$ & 0.39 & -0.38 & -0.41 & -0.50 & -0.35 \\
\hline DCA Axis 1 & 0.87 & -0.73 & -0.89 & -0.58 & 0.10 \\
\hline DCA Axis 2 & -0.58 & 0.48 & 0.39 & l & -0.51 \\
\hline
\end{tabular}

Values in bold are significant at $p<0.0001$

"/" no significant correlation

scores, indicating that Axis 1 reflects lake-level variation. The Spearman's test results (Table 1) display a positive correlation between the Cyclotella group and DCA Axis $1(\rho=0.87, p<0.0001)$, and a negative correlation between the facultative planktonic and benthic group and DCA Axis $1(\rho=-0.73$ and $-0.58, p<0.0001$, respectively), emphasizing the influence of lake level in the data. Axis 2 scores 
(eigenvalue $=0.23$ ) reflect a clear trophic gradient between oligo-mesotrophic taxa, which include the Cyclotella complex and Eolimna submuralis (Hustedt) Lange-Bertalot et Kulikovskiy that have relatively low scores on Axis 2, and meso-eutrophic species Aulacoseira granulata (Ehrenberg) Simonsen, Aulacoseira ambigua (Grunow) Simonsen, Staurosirella berolinensis (Lemmermann) Bukhtiyarova, Stephanodiscus minutulus (Kützing) Cleve et Möller and Stephanodiscus rotula (Kützing) Hendey, which have high scores. Based on the hypothesized resource relationships among the planktonic diatoms (Kilham et al. 1986), increased abundance and/or dominance of $A$. granulata in core Co1215, is indicative of eutrophic, low-light and turbid-water conditions, whereas $A$. ambigua stages reflect more stable lake stratification, higher light availability and a meso-eutrophic state. From the Spearman test, the trophic gradient is supported by the negative correlation between the Cyclotella group and E. submuralis to DCA Axis 2
( $\rho=-0.58$ and $-0.51, p<0.0001$, respectively). $E$. submuralis has been described as an epiphytic species from the littoral and sub-littoral zone of Lake Ohrid (Hustedt 1945). Diatoms are compared in Fig. 5 to selected geochemical, isotope and pollen data from the core according to the chronology of MIS boundaries (Lisiecki and Raymo 2005). Description of the diatom zones (D):

D1: 1,760-1,530 cm depth, 91.0-78.0 cal ka BP

Dla (1,760-1,652 cm depth, 91.0-85.5 cal ka BP)

Planktonic, facultative planktonic (FP) and benthic taxa are present in approximately equal proportions at the base of the sequence, with minor fluctuations between groups, until an increasing trend in FP at the expense of benthic taxa occurs at $90.0 \mathrm{cal} \mathrm{ka} \mathrm{BP}$, reaching a maximum of $>80 \%$ at $85.5 \mathrm{cal} \mathrm{ka} \mathrm{BP}$. Planktonic Cyclotella ocellata Pantocsek and C. paraocellata

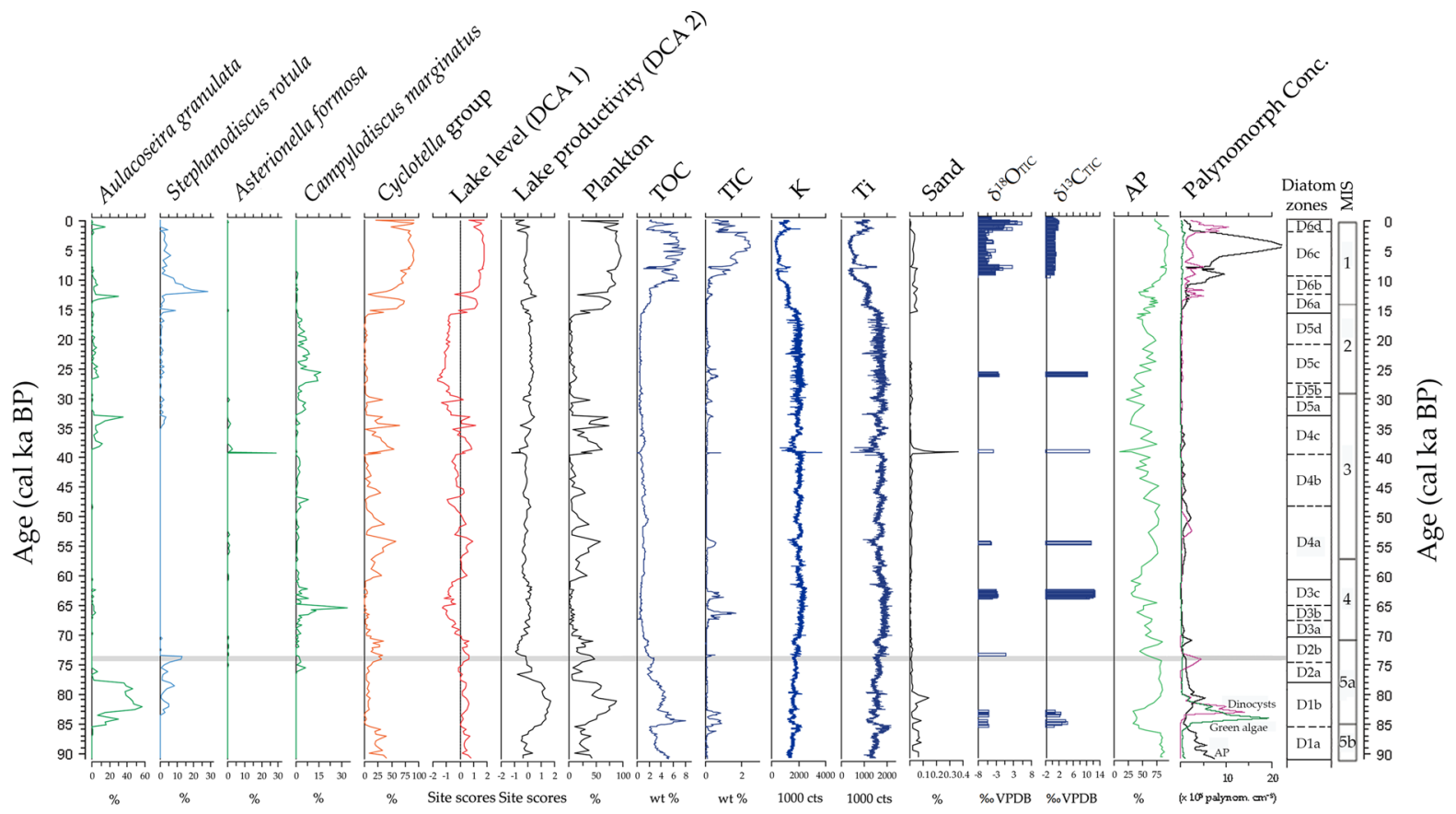

Fig. 5 Diagram of Lake Prespa core Co1215 displaying: abundance $(\%)$ of selected diatom taxa, DCA Axis 1 (lakelevel) and DCA Axis 2 (lake productivity) scores and diatom plankton (\%) abundance. Previously published data include total organic carbon (TOC; wt \%), total inorganic carbon (TIC; wt \%), potassium (K; $1,000 \mathrm{cts})$, titanium (Ti; $1,000 \mathrm{cts})$, sand $(\%)$ (Wagner et al. 2012), $\delta^{18} \mathrm{O}_{\mathrm{TIC}}(\% \mathrm{VPDB}), \delta^{13} \mathrm{C}_{\mathrm{TIC}}$ (\%)VPDB) (Leng et al. 2013), arboreal pollen (\%) and concentrations $\left(\times 10^{5}\right)$ of arboreal pollen (AP; black), green algae (green) and dinoflagellates (purple) (Panagiotopoulos et al. 2014). Light gray band marks the Dreissena shell horizon between 14.58 and $14.63 \mathrm{~m}$ depth, $c a .73 .57 \pm 7.74 \mathrm{ka}$ (Damaschke et al. 2013). CONISS-delineated diatom zones are marked. Marine Isotope Stage (MIS) boundaries are from Lisiecki and Raymo (2005). (Color figure online) 
Cvetkoska, Hamilton, Ognjanova-Rumenova et Levkov are each present at $>20 \%$, while $C$. prespanensis Cvetkoska, Hamilton, Ognjanova-Rumenova et Levkov is rare, at $<5 \%$ relative abundance. $E$. submuralis is the most abundant benthic species, exhibiting a peak of $22 \%$ at $88.0 \mathrm{cal} \mathrm{ka}$ BP. Other common benthic taxa are Amphora spp., Diploneis spp., Navicula hastata Jurilj and Navicula spp.

\section{DIb (1,652-1,530 cm depth, 85.5-78.0 cal ka BP)}

Zone D1b is marked by a shift to dominance of planktonic Aulacoseira Thwaites taxa, increasing to $>50 \%$ at $84.2 \mathrm{cal}$ ka BP. A. granulata and A. ambigua co-dominate initially, with $A$. granulata dominating thereafter $(>35 \%)$ until $78.0 \mathrm{cal} \mathrm{ka} \mathrm{BP.} A$. ambigua is at low abundance except for two peaks of $>35 \%$ at $83.0 \mathrm{cal} \mathrm{ka} \mathrm{BP}$ and $81.2 \mathrm{cal} \mathrm{ka} \mathrm{BP}$. FP and benthic taxa increase to $>30$ and $10 \%$, respectively, from $81.0 \mathrm{cal} \mathrm{ka} \mathrm{BP.}$

D2: 1,530-1,364 cm depth, 78.0-70.2 cal ka BP

D2a $(1,530-1,474,78.0-74.5$ cal ka BP $)$

Subzone D2a marks a sharp decline in the abundance of A. granulata and renewed dominance of small Fragilariaceae. Benthic species dominate in a single sample at $76.7 \mathrm{cal} \mathrm{ka} \mathrm{BP}$, at $70 \%$ abundance, a consequence of peak abundance ( $\sim 60 \%)$ of E. submuralis.

\section{D2b (1,474-1,364 cm depth, 74.5-70.2 cal ka BP)}

Plankton increases in D2b, but stays below $50 \%$. In two assemblages, at $73.4 \mathrm{cal} \mathrm{ka} \mathrm{BP}$ and $70.9 \mathrm{cal}$ ka BP, all habitat groups are present at similar abundance. Small Fragilariaceae reach a maximum of $38 \%$ at the upper zone boundary. Benthic species are diverse and dominate from 73.0 to $71.5 \mathrm{cal} \mathrm{ka} \mathrm{BP}$, with a peak of $71 \%$ at $72.8 \mathrm{cal}$ ka BP. Amphora spp., Campylodiscus spp., Diploneis cf. krammeri LangeBertalot et Reichardt, Diploneis sp., Fallacia ohridana (Hustedt) Levkov et Krstic, Gyrosigma attenuatum (Kützing) Cleve, E. submuralis, Navicula spp., Nitzschia spp. Hassall and Surirella spp. Turpin are most abundant within the group.
D3:1,364-1,086 cm depth, 70.2-60.7 cal ka BP

D3a (1,364-1,284 cm depth, 70.2-67.5 cal ka BP)

Small Fragilariaceae exhibit a consistent increasing trend to $\sim 60 \%$ abundance, driven by $S$. pinnata. Plankton is at $<15 \%$ abundance. Benthic taxa decline to $\sim 35 \%$ at the upper zone boundary, with $E$. submuralis and $G$. attenuatum being most common, peaking at $34 \%$ abundance at $70.0 \mathrm{cal} \mathrm{ka} \mathrm{BP}$ and $27 \%$ at $68.7 \mathrm{cal} \mathrm{ka} \mathrm{BP,} \mathrm{respectively.}$

D3b (1,284-1,212 cm depth, 67.5-65.0 cal ka BP)

Plankton continues to decrease and is mainly represented by Cyclotella spp. $(<8 \%)$ and A. granulata $(<5 \%)$. High Staurosira spp. and S. pinnata abundance at the base of the subzone is replaced by increasing benthic species abundance to $\sim 80 \%$ at 65.5 cal ka BP, marked by a distinct peak (34\%) of Campylodiscus marginatus Jurilj.

D3c (1,212-1,086 cm depth, 65.0-60.7 cal ka BP)

Low plankton abundance $(<8 \%)$ is maintained in subzone D3c. Small Fragilariaceae are present at 45-70\% throughout. The benthic group increases to 25-50\% abundance throughout the zone. A single peak $(6 \%)$ in the record of the aerophilous Ellerbeckia arenaria (Moore ex Ralfs) Crawford occurs at $62.5 \mathrm{cal} \mathrm{ka}$ BP. The benthic group is represented by species similar to those in zone $D 2 b$.

D4:1,086-667 cm depth, 60.7-33.0 cal ka BP

D4a (1,086-904 cm depth, 60.7-48.1 cal ka BP)

Subzone D4a is marked by fluctuating abundance of all species groups. Cyclotella species increase from the base of the zone, to $60 \%$ at $54.3 \mathrm{cal} \mathrm{ka} \mathrm{BP}$, at the expense of FP, while benthic taxa maintain 40-50\% abundance. Among them, E. submuralis is most abundant (10-20\%), while Amphora spp. reach maximum abundance of $9 \%$ at $58.4 \mathrm{cal} \mathrm{ka} \mathrm{BP}$. At 53.4 cal ka BP small FP start to increase towards the upper zone boundary, reaching $>50 \%$ at $49.6 \mathrm{cal} \mathrm{ka}$ $\mathrm{BP}$, while at same time, the benthic group decreases to $35 \%$. 
D4b (904-776 cm depth, 48.1-39.3 cal ka BP)

Plankton remains below $10 \%$ in subzone D4b, apart from the peak at $46.0 \mathrm{cal} \mathrm{ka} \mathrm{BP}$ when $C$. prespanensis peaks at $20 \%$. The zone exhibits high diversity and co-dominance of FP and benthic taxa. E. submuralis is present throughout, at up to $25 \%$ abundance. Other abundant benthic species in this subzone are Cocconeis spp., Cavinula scutelloides (Smith) LangeBertalot, Cavinula cf. cocconeiformis var. elliptica (Hustedt) Lange-Bertalot, D. krammeri, Diploneis sp. and Pinnularia subrupestris Krammer.

\section{D4c (776-667 cm depth, 39.3-33.0 cal ka BP)}

The only peak of Asterionella formosa Hassall $(\sim 30 \%)$ in the record occurs at $39.3 \mathrm{cal} \mathrm{ka} \mathrm{BP}$, accompanied by peak abundance (22\%) of Nitzschia palea (Kützing) Smith. The planktonic C. ocellata, Stephanodiscus hantzschii Grunow, facultative planktonic Pseudostaurosira brevistriata (Grunow) Williams et Round, S. pinnata and the benthic species Fallacia helensis (Schulz) Mann, G. attenuatum and Navicula spp. compose the diatom assemblage at 39.3 cal ka BP, all of them present at similar abundance. At $38.6 \mathrm{cal} \mathrm{ka} \mathrm{BP}, C$. ocellata is present at $32 \%$, accompanied by a $17 \%$ peak of Cyclotella minuscula (Jurilj) Cvetkoska.

After a minimum of $<10 \%$ at $35.2 \mathrm{cal} \mathrm{ka} \mathrm{BP,}$ plankton increases again, a consequence of a peak in Cyclotella abundance ( $65 \%)$. At 34.3 cal ka BP Cyclotella spp. decline again and are replaced by increasing A. granulata, which becomes dominant in the plankton at the upper zone boundary. FP dominate only at $35.2 \mathrm{cal} \mathrm{ka}$ BP. The benthic group is dominant from 39.0 to 34.2 cal ka BP. From 36.2 cal ka BP, E. submuralis declines to $<5 \%$.

D5: 667-293 cm depth, 33.0-15.7 cal ka BP

\section{D5a (667-611 cm depth, 33.0-29.7 cal ka BP)}

Subzone D5a is co-dominated by benthic and FP species. C. ocellata displays a single peak of $30 \%$ at $30.4 \mathrm{cal}$ ka BP. G. attenuatum is the dominant benthic species (12-23\% abundance) until 30.9 cal ka BP, when it declines and Diploneis alpina Meister peaks at $22 \%$. Amphora spp., C. marginatus, Cocconeis spp.,
Diploneis mauleri (Brun) Cleve and Gyrosigma macedonicum Levkov, Krstic et Nakov are common.

D5b (611-556 cm depth, 29.7-27.3 cal ka BP)

Subzone D5b maintains low plankton abundance $(<5 \%)$. Small FP species prevail until $27.8 \mathrm{cal} \mathrm{ka}$ $\mathrm{BP}$, when benthic taxa increase to $>55 \%$. The benthic group is of similar composition to that in D5a.

D5c (556-405 cm depth, 27.3-21.0 cal ka BP)

Low plankton abundance $(<15 \%)$ is maintained throughout D5c, with Aulacoseira granulata present at $<10 \%$. At $27.1 \mathrm{cal} \mathrm{ka} \mathrm{BP,} \mathrm{the} \mathrm{maximum} \mathrm{benthic}$ abundance of $75 \%$ is dominated by D. alpina (35\%) and $C$. marginatus $(15 \%)$. Benthic domination is replaced by small Fragilariaceae, from $25.4 \mathrm{cal} \mathrm{ka}$ BP, mainly because of increased abundance of $S$. pinnata.

D5d (405-293 cm depth, 21.0-15.7 cal ka BP)

In subzone D5d small Fragilariaceae continue to increase as benthic taxa decrease, with $S$. pinnata being dominant at $>40 \%$ abundance throughout. Plankton remains at low abundance, with a maximum of $10 \%$ at the upper zone boundary. Among the benthic species, $D$. alpina declines to $<10 \%$, while Diploneis sp. increases to $10 \%$ at $17.7 \mathrm{cal} \mathrm{ka} \mathrm{BP.}$

D6: 293-2 cm depth, 15.7 cal ka BP-present

D6a (293-220 cm depth, 15.7-12.3 cal ka BP)

Subzone D6a incorporates a shift at $15.7 \mathrm{cal} \mathrm{ka} \mathrm{BP} \mathrm{to}$ increased abundance of Cyclotella taxa ( $>25 \%)$. At 15.2 cal ka BP, $S$. rotula exhibits a minor peak of $\sim 9 \%$, which is followed by an increase in the relative proportion of S. pinnata ( $\sim 35 \%)$. From $14.8 \mathrm{cal} \mathrm{ka}$ BP, small Fragilariaceae decline and planktonic Cyclotella taxa dominate up to the upper zone boundary. The benthic group declines to $<20 \%$, and is similar to D5d. The $13.1-12.3$ cal ka BP interval comprises only two samples, but is distinct because of a peak of $30 \%$ in A. granulata at $12.9 \mathrm{cal} \mathrm{ka} \mathrm{BP,} \mathrm{and}$ of $S$. pinnata at the upper zone boundary. 
D6b (220-164 cm depth, 12.3-9.3 cal ka BP)

D6b is delineated by a peak in S. rotula $(\sim 30 \%)$ at the base of the zone and a sharp increase in planktonic taxa to $>70 \%$. After the initial peak, $S$. rotula declines towards the upper zone boundary, while the $C$. ocellata and $C$. paraocellata sum abundance increases to $\sim 70 \%$ at $10.5 \mathrm{cal} \mathrm{ka} \mathrm{BP}$. The FP decline from $\sim 20 \%$ at the base to $<5 \%$ at the upper zone boundary. The benthic group is present at $\sim 10-20 \%$ abundance throughout.

D6c (164-70 cm depth, 9.3-1.9 cal ka BP)

Subzone D6c is delineated by the highest plankton abundance, $>90 \%$ relative abundance, between 7.9 and $4.2 \mathrm{cal}$ ka BP. C. paraocellata dominates the planktonic group. C. minuscula peaks with $10 \%$ at 8.0 cal ka BP. Benthic taxa decline to $<10 \%$ after 7.9 cal ka BP.

\section{D6d (70-2 cm depth, 1.9 cal ka BP-present)}

C. ocellata becomes dominant at the expense of $C$. paraocellata, which declines sharply to $<10 \%$ abundance. C. minuscula peaks between 1.7 and $1.5 \mathrm{cal} \mathrm{ka}$ BP and at $0.5 \mathrm{cal}$ ka BP. A. granulata and Staurosira spp. peak at 15 and $25 \%$ relative abundance, respectively, at $1.0 \mathrm{cal} \mathrm{ka} \mathrm{BP}$, while from $0.3 \mathrm{cal} \mathrm{ka} \mathrm{BP}$ (seventeenth century $\mathrm{AD}$ ), there is a marked trend towards increasing dominance, for the first time, of the benthic species $C$. scutelloides. It reaches a maximum of $\sim 40 \%$ at $0.05 \mathrm{cal} \mathrm{ka} \mathrm{BP} \mathrm{(} \mathrm{ca}$. AD 1900), when benthic taxa dominate at $>60 \%$. The surface sediment sample is dominated by $C$. ocellata $(>80 \%$ ), accompanied by the benthic $N$. subacicularis Hustedt.

\section{Discussion}

\section{Diatom response}

Shifts in relative abundance of $C$. ocellata, $C$. paraocellata and $C$. prespanensis were interpreted in the late glacial to Holocene record as a response to shifts in trophic status within waters of low to medium productivity (Cvetkoska et al. 2014a). In the longer record, this is supported in part by the absence of more eutrophic taxa such as A. granulata in Cyclotella- dominated zones. Across a range of diatoms with contrasting P-availability and light-intensity preferences, Kilham et al. (1986) placed A. ambigua as intermediate between the oligotrophic, high-lightdemanding Aulacoseira distans (Ehrenberg) Simonsen, and the eutrophic, low-light $A$. granulata.

Dominance of small Fragilariaceae and the benthic E. submuralis likely reflect a shallow, low-productivity lake. S. pinnata is considered a typical glacial-type species, based on inferences for its high sensitivity to the climate-related variables "duration of ice cover" and "mean July water temperature" (Schmidt et al. 2004) and also its presence in glacial phases of other Mediterranean lakes such as Ioannina (Wilson et al. 2008; Jones et al. 2013). During interglacials, small Fragilariaceae tend to occur in marginal open lake waters at the start of the warming season and are often regarded as pioneering taxa with broad ecological preferences (Smol 1988).

The highly diverse benthic group is mainly represented by species with large, heavily silicified valves such as C. marginatus, D. alpina, G. attenuatum and Surirella spp., without major species turnover from the last interglacial to the present. Modern ecological studies (Levkov et al. 2007a, b) demonstrate that these species dominate as epipelic taxa in deeper waters (4-18 $\mathrm{m}$ ) and the physico-chemical properties of the lake (substrate, light intensity, dissolved oxygen, $\mathrm{Si}$ ) are the main factors that determine the structure of these communities.

MIS 5 (91.0-71.0 cal ka BP; D1, D2)

MIS 5b (91.0-85.0 cal ka BP; Dla)

Rapidly fluctuating lake levels during MIS $5 \mathrm{~b}$ are inferred from the shifts in Cyclotella abundance (10-45\%) in the basal diatom zone (Fig. 3) and positive, but low DCA Axis 1 scores (Fig. 4), overall representative of an intermediate, moderately deep lake. Minima at 90.0, 88.4 and $85.6 \mathrm{cal}$ ka BP indicate low-lake-level phases. The dominant Staurosira spp., S. construens and E. submuralis, reflect diatom growth restricted to the sandy, shallow and nutrient-depleted littoral zone.

Panagiotopoulos et al. (2014) suggest MIS 5b was a period of rather high lake productivity based on high AP $\%$ and green algae concentration, TOC and $\mathrm{C} / \mathrm{N}$ values. However, the diatoms indicate an oligo- 
mesotrophic state (Cvetkoska et al. 2014a), correlating with a decreasing trend in TOC values from the base of the sequence. The higher SAR (Fig. 2) and sand content (Fig. 5) indicate catchment erosion, supported by a gradual increase in $\mathrm{Ti}$ and $\mathrm{K}$, but apparently insufficient nutrients to generate high productivity.

Diatom-inferred intermediate moisture availability and possible (based on low productivity) relatively low temperatures in MIS 5b, are indicated more strongly by the absence of warm, sclerophyllous Mediterranean taxa in the pollen record between 91.0 and 85.0 cal ka BP, which suggests unfavorable winter temperatures for such vegetation around Lake Prespa (Panagiotopoulos et al. 2014). Overall, the data suggest a phase of unstable climate with moderate, but fluctuating moisture availability and temperature, which may reflect a transitional phase towards the end of the previous interglacial.

\section{MIS 5a (85.0-71.0 cal ka BP; D1b, D2)}

Initial dominance of a eutrophic diatom flora and high DCA Axis 2 scores indicative of high productivity, support inferences from rising Ti and K counts (Fig. 5) for increased allochthonus input and/or nutrient upwelling from the sediment. The peak in A. granulata correlates with high TOC at $c a$. 85.0-84.0 cal ka BP, a double peak in TIC between 85.0 and $83.0 \mathrm{cal} \mathrm{ka}$ BP and maximum concentration of green algae and dinocysts. Although diatom response is dominated by a productivity shift, low DCA Axis 1 scores also indicate low lake levels between 85.0 and $83.0 \mathrm{cal} \mathrm{ka}$ BP, correlated with peaks of Artemisia (32\%) and Chenopodiaceae (12\%), indicative of drought (Panagiotopoulos et al. 2014). As in the upper record, productivity may be high in low-lake-level phases, in particular when wind-induced mixing causes nutrient re-suspension from bottom sediments. This is at odds with inferences for low evaporative concentration based on relatively low $\delta^{18} \mathrm{O}(-5$ to $-4 \%$ ) values.

A second lake low-stand is inferred between 77.6 and $76.6 \mathrm{cal} \mathrm{ka}$ BP from diatoms and low DCA Axis 1 scores. The occurrence of ice rafted debris (IRD) for the first time in the sediment record of Lake Prespa (Damaschke et al. 2013) provides strong evidence that the lake was ice-covered during the winter season, and along with the decline in Quercus pollen (Panagiotopoulos et al. 2014), supports the lake low-stand being triggered by decreased precipitation during cold/dry 'glacial' climate conditions. A diatom-inferred moderate increase in lake level and moisture availability after $76.6 \mathrm{cal}$ ka BP is clear from Cyclotella abundance and DCA Axis 1 scores; the lack of sensitivity of other proxy indicators suggests high diatom sensitivity to a phase of subtle climate change at the end of the last interglacial, until $70.2 \mathrm{cal} \mathrm{ka}$ BP.

The most distinct horizon in the core is the Dreissena presbensis shell layer, at $73.6 \pm 7.7 \mathrm{ka}$ (Damaschke et al. 2013), and a lake level low-stand in Lake Prespa (and potentially Lake Ohrid) has been inferred from a combination of seismic, isotope and pollen data (Wagner et al. 2012; Leng et al. 2013; Panagiotopoulos et al. 2014). Wagner et al. (2014c) recognize tectonic events or karst processes as a possible cause of this low-stand, but also note its intriguing chronological correspondence to the $74 \mathrm{ka}$ BP eruption of the Toba volcano. A peak in abundance of mesotrophic $S$. rotula $(\sim 15 \%)$, in an assemblage dominated by the Cyclotella group, occurs at $73.6 \mathrm{cal} \mathrm{ka}$ BP. This can indicate a mixed diatom assemblage, not correlated completely with the shell horizon, or increasing lake levels immediately after its deposition. Higher-resolution analysis is needed to test these scenarios.

\section{MIS 4 (71.0-57.0 cal ka BP; D3, part of D4a)}

The diatoms and low DCA Axis 2 scores in zone D3 reflect low lake productivity and match well with the silty sediments and low organic content of lithofacies 1 (Damaschke et al. 2013), reflecting glacial onset. Dominance of small Fragilariaceae, E. submuralis and Cocconeis spp. implies that diatom growth was mainly restricted to ice-free, shallow littoral habitats, most likely during a short growing season. S. pinnata, at $30 \%$ abundance, points to prolonged ice cover and low mean summer temperatures. The high abundance of large, heavily silicified benthic species throughout the zone, such as G. attenuatum, Campylodiscus spp. and $D$. mauleri, does not reflect increased productivity, because growth was probably facilitated by high water transparency, resulting from low plankton concentration in the epilimnion during the glacial, and points to a sufficient $\mathrm{Si}$ supply, necessary for formation of their large, complex frustules. Relatively high $\mathrm{Ti}$ and $\mathrm{K}$ values and SAR between 70.0 and $60.0 \mathrm{cal}$ ka BP indicate high catchment erosion, most likely caused by greater input of ice-melt water during 
the spring/summer season, in agreement with the simultaneous opening of the landscape (Panagiotopoulos et al. 2014).

The low DCA Axis 1 scores and Cyclotella group at $<10 \%$ provide strong evidence for lake-level decline since MIS 5, indicative of glacial aridity in MIS 4 . The maximum benthic abundance $(85 \%)$ at $65.5 \mathrm{cal} \mathrm{ka}$ $\mathrm{BP}$ is synchronous with distinct minima in the AP percentages in the pollen record, indicative of low moisture availability.

\section{MIS 3 (57.0-29.0 cal ka BP; D4, D5a)}

Positive DCA Axis 1 scores and Cyclotella (>10\%) suggest increased lake level as a rapid response to increased moisture availability at the start of MIS 3 . Phases of low lake level within the time period are indicated by peaks in small Fragilariaceae and $E$. submuralis between 49.0-46.6 and 45.0-39.5 cal ka $\mathrm{BP}$ and correlate with high erosion inferred from high $\mathrm{Ti}$ and $\mathrm{K}$ values (Wagner et al. 2012). Although the interstadial climate was relatively warm, the diatoms, low DCA Axis 2 scores and the relatively low TOC and TIC, suggest low productivity and/or higher decomposition of the organic matter until $38.2 \mathrm{cal}$ ka BP.

An unusual shift at $39.28 \mathrm{cal} \mathrm{ka} \mathrm{BP,} \mathrm{to} \mathrm{a} \mathrm{species}$ richness of $<10$ in a diatom assemblage co-dominated by $A$. formosa $(\sim 30 \%)$ and N. palea $(\sim 20 \%)$, can be ascribed to the influence of the PT0915-7/Y-5 tephra deposition, fingerprinted to the CI eruption of the Campi Flegrei caldera, considered the most explosive eruption in Europe over the last $c a .200 \mathrm{ka}$ (Barberi et al. 1978; Fitzsimmons et al. 2013). Tephra influx increases the silica content in the water (Barker et al. 2000) and in the case of Lake Prespa, both dominant species require a high Si:P ratio and have maximum growth rates at temperatures below $20{ }^{\circ} \mathrm{C}$ (Holm and Armstrong 1981). The tephra deposition most likely altered the lake water chemistry and the benthic habitats, and caused a shift in conditions that reduced the diversity of ecological niches and favored only a few species. The diatom data, the high SAR, spike in TIC, low TOC (Wagner et al. 2012; Damaschke et al. 2013), low $\mathrm{C} / \mathrm{N}$ and $\delta^{18} \mathrm{O}(-2.8 \%$; Leng et al. 2013), and extremely low AP ( $\sim 10 \%$; Panagiotopoulos et al. 2014), suggest that the CI eruption enhanced climate aridity and/or cooling, which affected both the lake and its catchment area.
The subsequent peak of $C$. minuscula at $38.7 \mathrm{cal} \mathrm{ka}$ BP indicates nutrient enrichment, possibly representing a lag response to the tephra deposition, as in the appearance of small-sized species and the single appearance of $S$. minutulus in Lake Ohrid core Co1202 (Cvetkoska et al. 2012) after tephra deposition associated with the FL eruption of Etna at $3.4 \mathrm{cal} \mathrm{ka}$ BP (Wagner et al. 2008b; Vogel et al. 2010). The increasing abundance of A. granulata thereafter, suggests relatively high trophic status was maintained until 33.0 cal ka BP. Similar shifts in the structure and productivity of the diatom assemblages caused by volcanic disturbance were also noted in other parts of the world, for example Lake Galletué in the Chilean Andes (Cruces et al. 2006). The subsequent return to dominance of small Fragilariaceae and benthic taxa indicates renewed aridification and/or cooling, supporting palynological inferences that define the end of MIS 3 at 29.0 cal ka BP.

\section{MIS 2 (29.0-14.0 cal ka BP; D5b-d, part of D6a)}

The diatoms and low DCA Axis 1 scores at the base of zone D5c point to low lake levels and mark the onset of the Last Glacial Maximum (LGM) in Lake Prespa (Clark et al. 2009). The concurrent TIC spike, siderite precipitation and high $\delta^{13} \mathrm{C}$ imply within-sediment reducing conditions and methanogenesis (Leng et al. 2013). The overall high facultative planktonic and benthic abundance between 29.0 and $15.7 \mathrm{cal} \mathrm{ka}$ BP reflects a shift in the hydrological balance, most likely triggered by reduced moisture availability and low temperatures at the time of the LGM, as also indicated by the domination of open vegetation in the catchment (Panagiotopoulos et al. 2014). The low DCA Axis 2 scores reflect low productivity of the lake, as indicated by low TOC and TIC values, and may be assigned to the lower biomass available in the catchment, as suggested by the pollen concentration curve (Panagiotopoulos et al. 2014).

The onset of late glacial warming and increased moisture availability is indicated from $15.7 \mathrm{cal}$ ka BP by a diatom-inferred increase in lake level, correlating with rising TOC values. The shift in dominance of $A$. granulata and S. pinnata between 13.1 and $12.3 \mathrm{cal} \mathrm{ka}$ $\mathrm{BP}$ has been interpreted as strong evidence for the Younger Dryas climate reversal. According to the age model presented in Aufgebauer et al. (2012), the "YD" event in Lake Prespa has an earlier onset than in 
most sites, where it tends to occur from 12.8 to $11.7 \mathrm{ka}$ (cf. Alley 2000). The diatoms support previous inferences derived from the pollen record (Panagiotopoulos et al. 2013) and probably represent a nutrient pulse linked to enhanced catchment erosion caused by a combination of lake-level reduction and wind stress (Cvetkoska et al. 2014a).

The Holocene (14.0 cal ka BP-present, part of D6a, D6b-D6d)

The gradual transition to the Holocene, and diatom response to Holocene climate change and human impact in Lake Prespa, was discussed in detail by Cvetkoska et al. (2014a). A middle Holocene (7.9-1.9 cal ka BP) phase of high diatom-inferred lake levels and humidity, peaking from 7.9 to $6.0 \mathrm{cal} \mathrm{ka} \mathrm{BP}$, is the most important feature. After 1.9 cal ka BP, intensified human impact and associated increases in nutrient status occur, along with two lake-level declines at 1.0 and $0.1 \mathrm{cal} \mathrm{ka} \mathrm{BP.} \mathrm{The}$ prominent climatic aridity at $1.0 \mathrm{cal} \mathrm{ka} \mathrm{BP}$ is also noted in sediment records from Lake Ohrid (Wagner et al. 2009; Vogel et al. 2010; Lacey et al. 2014).

Comparison with other records

\section{Diatom response thresholds}

Few long-term diatom studies have been carried out in the Mediterranean, but there are two relevant studies in close proximity to Lake Prespa. Published data from the Co1202 diatom record from Prespa's sister lake, Lake Ohrid (Fig. 6) span the last ca. 140 cal ka BP (Vogel et al. 2010). Published data from ancient Lake Ioannina, Greece, is currently restricted to MIS 4 to present (Fig. 6) and the earlier interglacial-glacial transition at $c a$. 189-170 ka (Wilson et al. 2013). Lakes Prespa, Ohrid and Ioannina all show strong diatom responses to orbital and suborbital climate variability, but the results of this study confirm clear contrasts in response mechanisms. A good example is the evidence for climate warming and wetting during MIS 3. As a deep lake system, Ohrid's strong diatom response appears to be driven by temperature-induced productivity change (Reed et al. 2010; Cvetkoska et al. 2012), whereas the Prespa signal is one of increasing moisture availability, underlining the importance of changes in precipitation in spite of increased temperature-induced evaporation. This is evident in MIS 5a when the low lake levels induced by drought accelerated the eutrophication of Lake Prespa. This suggests that in Lake Prespa, the hydrological balance is crucial, and future drought would cause serious consequences to the lake and its biota.

Comparison of glacial and interglacial taxonomic shifts also highlights contrasting drivers of ecological response in groups of diatom taxa, indicating that a 'transfer-function' approach incorporating simple response to climate variables is invalid. All the lakes were dominated by the Cyclotella ocellata complex during interglacials, but, as in MIS 3, with a contrast in productivity (Ohrid) versus moisture availability (Prespa, Ioannina) as drivers. Preservation of diatoms during glacial phases also differs between deep Lake Ohrid, which exhibits monospecific dominance by the planktonic C. fottii/hustedtii complex, and the shallower lakes, where small Fragilariaceae dominate in glacial phases and are thus taken as indicators of a cold, arid climate. In contrast, Reed et al. (2010) note that in Ohrid these taxa are strongly indicative of initial glacial-interstadial warming, as productivity increased in the littoral zone. The similarity in response mechanisms between Prespa and Ioannina supports the validity of direct comparison. There is evidence for a strong response to the YD climate reversal and initial warming/wetting at the Holocene transition in both sites, based on a switch from small Fragilariales to Cyclotella ocellata, but a major divergence in the timing of middle Holocene humidity. Whereas in Lake Prespa high lake levels are maintained until 1.9 cal ka BP (Cvetkoska et al. 2014a), lake-level decline in Ioannina started at 7.0 cal ka BP (Jones et al. 2013). In terms of climate change, this would suggest disparity in moisture availability at both sites, but nevertheless, the lake low-stand at Ioannina might be the culmination of a longer-term trend toward natural lake infilling (Jones et al. 2013) rather than a simple climate response. Future research on longer records is required to test this.

\section{Sub-orbital climate variability}

During the last glacial, six episodes of massive iceberg discharges, named Heinrich $(\mathrm{H})$ events, reduced ocean deep-water formation and caused cooling of the North Atlantic (Bond et al. 1993). Potential correlations with 


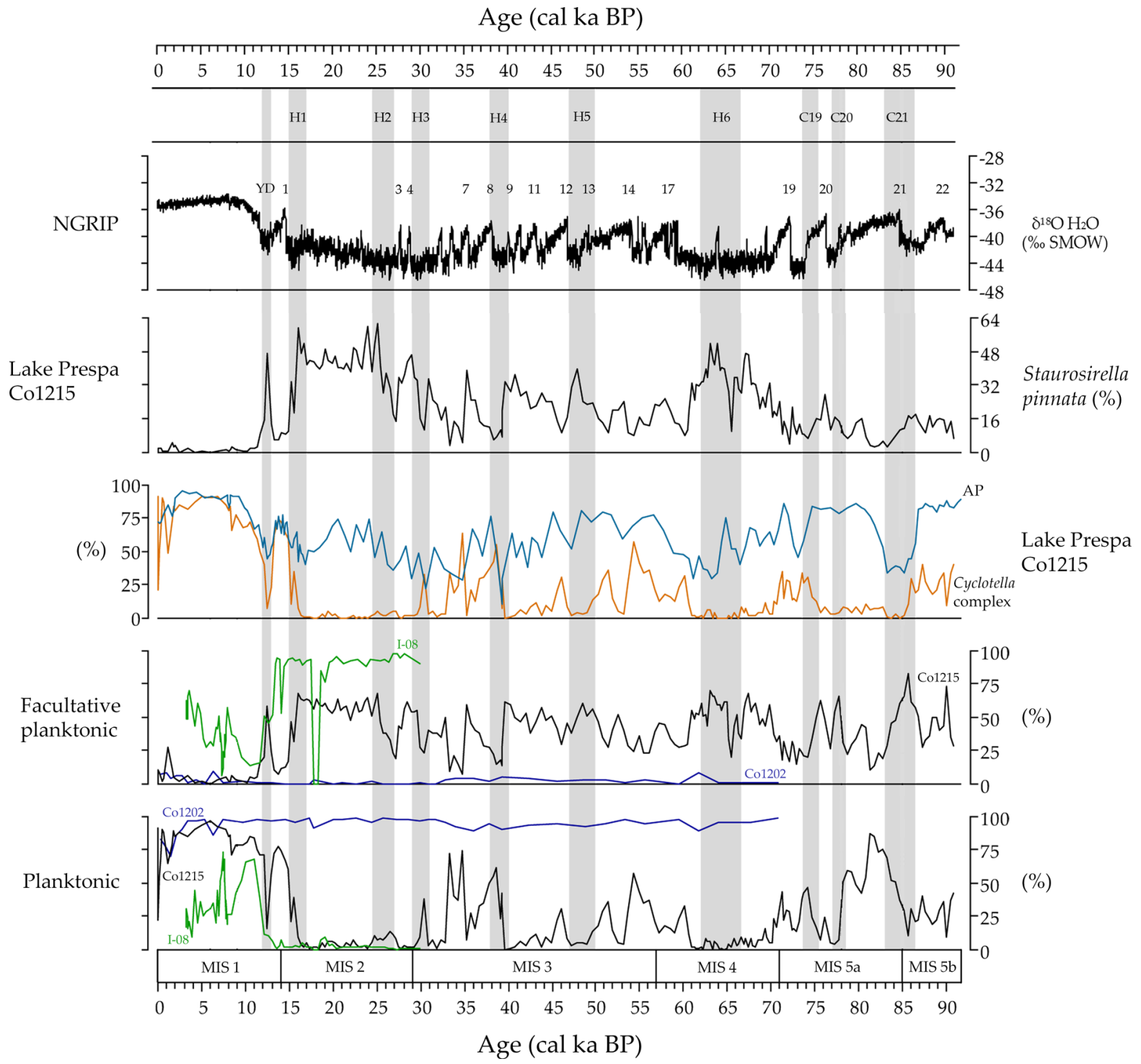

Fig. 6 Relative abundance (\%) of planktonic and facultative planktonic taxa compared between Lake Prespa core Co1215 (black; this study), Lake Ohrid core Co1202 (blue; Reed et al. 2010) and Lake Ioannina core I-08 (green; data from Jones et al. 2013). The relative abundance (\%) of the Cyclotella complex (orange, this study), interpreted as a proxy record of lake-level variations in Lake Prespa, is compared to arboreal pollen (AP, blue) percentages from core Co1215 (Panagiotopoulos et al.

and differences between $\mathrm{H}$ events and several shortterm hydrological changes at Lake Prespa, are defined by distinct peaks in Mn and TIC from core Co1204 (Wagner et al. 2010). By interpreting several distinct minima in the AP percentages in core Co1215 as reflecting the influence of Heinrich events on Lake Prespa catchment vegetation, and comparing existing
2014) and relative abundance of $S$. pinnata (\%; this study) and $\delta^{18} \mathrm{O} \mathrm{H}_{2} \mathrm{O}$ (\% SMOW) of the NGRIP ice core record (GICC05); the Dansgaard/Oeschger (D/O) warming events/Greenland interstadials (GI) are numbered. Explanation: MIS (Marine Isotope Stages) from Lisiecki and Raymo (2005), gray bands mark the H1-6 (Heinrich events) and the Younger Dryas (YD) as in Panagiotopoulos et al. (2014) and the C19-21 ice-rafting events (Chapman and Shackleton 1999). (Color figure online)

proxy data from lakes Ohrid and Prespa with the ages of the $\mathrm{H}$ events, Panagiotopoulos et al. (2014) hypothesized that the northern Mediterranean was influenced by rapid climate change in the North Atlantic. It is possible to test this hypothesis further using the strong proxy data for hydrological shifts. As noted, $S$. pinnata is typical of glacial environments in 
Lake Prespa and its abundance curve displays a very close match to the GICC05 $\delta^{18} \mathrm{O}$ record (GICC05modelext 2010) by increased values during the GS (Greenland Stadial) and distinct declines at the beginning of the GI (Greenland Interstadial). For example, the diatom-inferred low lake stand at 85.6 cal ka BP coincides with GS $22(\sim 88-85 \mathrm{ka}$; NGRIP members 2004) and the minimum in benthic $\delta^{13} \mathrm{C}$ during the $\mathrm{C} 21$ ice-rafting episode at $\sim 86 \mathrm{ka}$ (Chapman and Shackleton 1999). The lake low stand from 77.6 to $76.6 \mathrm{cal} \mathrm{ka}$ BP correlates to the GS 21 (77.8-76.4 ka; Wolff et al. 2010).

Peaks of $S$. pinnata, coincident with distinct declines in the Cyclotella complex abundance at $65.5 ; 29.0 ; 25.0$ and $16.0 \mathrm{cal} \mathrm{ka}$ BP are correlated to the AP minima in the pollen record, implying a well synchronized response between the catchment vegetation and the lake to the potential impact of the H6, H3-1 events. The impact of the H5 event (48.0 cal ka BP) was described as less severe on the arboreal catchment vegetation (Panagiotopoulos et al. 2014), however, the Cyclotella complex abundance $(<8 \%)$ between 49.0 and $46.6 \mathrm{cal} \mathrm{ka}$ BP implies that the H5 event had a more severe influence on the lake. The H4 event has been described as most severe on the catchment vegetation, enhanced by the Campanian Ignimbrite volcanic eruption at 39.3 cal ka BP (Panagiotopoulos et al. 2014). The diatoms also prove the severity of the H4 event and the Y5 tephra deposition, but disentangling their respective influences is difficult, because it appears that the diatom record primarily reflects the tephra impact. The distinct minimum in the Cyclotella complex at $25.0 \mathrm{cal} \mathrm{ka} \mathrm{BP}$ is approximately comparable to the $\mathrm{H} 2$ event in the diatom record from Les Echets (Ampel et al. 2008). Overall, we infer that North Atlantic forcing has had a major influence on climate variability in Lake Prespa on a variety of timescales since MIS 5.

\section{Conclusions}

The diatom record of Lake Prespa core Co1215 and the multi-proxy approach in the interpretation demonstrate an outstanding potential for inferring past climate change in this area at orbital and sub-orbital scales. The glacial-interglacial shifts in species assemblage composition support the notion that precipitation drives the diatom response, enabling confident interpretation of changes in moisture availability. The sensitivity of the lake and its biota to changes in the hydrological balance, and hence shifts in nutrient status, are the most notable elements of variation since MIS 5 to the present.

The imprint of rapid climate variations in the diatom record is readily apparent, implying that North Atlantic forcing was the prime factor driving changes in Lake Prespa over the last $91.0 \mathrm{cal}$ ka. Indeed, variations in the relative abundances of $S$. pinnata and the Cyclotella complex can be regarded as indicative of differences in the intensity of the impact of glacial Heinrich events on the lake, implying that the H2, H5 and $\mathrm{H} 6$ events were probably more severe than $\mathrm{H} 1$ and $\mathrm{H} 3$. The imprint of $\mathrm{H} 4$ needs future clarification, to disentangle the effects of climate and tephra influx on the diatom flora. Still, more diatom data from longer regional records are required to test temporal and spatial variation of moisture availability in the northern Mediterranean.

Acknowledgments The authors thank the Alexander von Humboldt Foundation for financial support of the project "Reconstruction of past environmental variations in ancient Lake Ohrid, a diatom inferred perspective." The project was partly funded by the German Research Foundation (DFG) within the scope of the Project B2 of the Collaborative Research Center 806 "Our Way to Europe." We thank Paul B. Hamilton, Canadian Museum of Nature, Canada, for helpful discussions about palaeolimnology and Mrs. Danijela Mitić Kopanja, Institute of Biology, Faculty of Natural Sciences, Skopje, Macedonia for technical assistance. We also thank our colleagues in the Institute of Geology and Mineralogy and the Seminar of Geography and Education (University of Cologne) for help in the field and in the lab. We are grateful to Dr. Timothy Jones, Lancaster Environment Centre, Lancaster University, UK for providing diatom data from Lake Ioannina core I-08.

\section{References}

Alley RB (2000) The younger dryas cold interval as viewed from central Greenland. Quat Sci Rev 19:213-226

Ampel L, Wohlfarth B, Risberg J, Veres D (2008) Paleolimnological response to millennial and centennial scale climate variability during MIS 3 and 2 as suggested by the diatom record in Les Echets, France. Quat Sci Rev 27:1493-1504

Ampel L, Bigler C, Wohlfarth B, Risberg J, Lotter AF, Veres D (2010) Modest summer temperature variability during DO cycles in western Europe. Quat Sci Rev 29:1322-1327

Aufgebauer A, Panagiotopoulos K, Wagner B, Schäbitz F, Viehberg FA, Vogel H, Zanchetta G, Sulpizio R, Leng MJ, Damaschke M (2012) Climate and environmental change 
in the Balkans over the last $17 \mathrm{ka}$ recorded in sediments from Lake Prespa (Albania/F.Y.R. of Macedonia/Greece). Quat Int 274:122-135

Barberi F, Innocenti F, Lirer L, Munno R, Pescatore TS, Scandone R (1978) The Campanian Ignimbrite: a major prehistoric eruption in the Neapolitan area (Italy). Bull Volcanol 41:10-22

Barker P, Telford R, Merdaci O, Williamson D, Taieb M, Vincens A, Gibert E (2000) The sensitivity of a Tanzanian crater lake to catastrophic tephra input and four millennia of climate change. The Holocene 10:303-310

Battarbee RW (1986) Diatom analysis. In: Berglund BE (ed) Handbook of Holocene palaeoecology and palaeohydrology. Wiley, Chichester, pp 527-570

Bond G, Broecker W, Johnsen S, McManus J, Labeyrie L, Jouzel J, Bonani G (1993) Correlations between climate records from North Atlantic sediments and Greenland ice. Nature 365:143-147

Chapman MR, Shackleton NJ (1999) Global ice-volume fluctuations, North Atlantic ice-rafted events, and deep-ocean circulation changes between 130 and $70 \mathrm{ka}$. Geology 27:795-798

Clark PU, Dyke AS, Shakun JD, Carlson AE, Clark J, Wohlfarth B, Mitrovica JX, Hostetler SW, McCabe AM (2009) The last glacial maximum. Science 325:710-714

Cruces F, Urrutia R, Parra O, Araneda A, Treutler H, Bertrand S, Fagel N, Torres L, Barra R, Chirinos L (2006) Changes in diatom assemblages in an Andean lake in response to a recent volcanic event. Arch Hydrobiol 165(1):23-35

Cvetkoska A, Reed JM, Levkov Z (2012) Diatoms as indicators of environmental change in ancient Lake Ohrid during the last glacial-interglacial cycle (ca $140 \mathrm{ka}$ ). In: Witkowski A (ed) Diatom monographs, vol 15. ARG Gartner Verlag, Ruggell, Liechtenstein, p 220

Cvetkoska A, Hamilton PB, Ognjanova-Rumenova N, Levkov Z (2014a) Observations of the genus Cyclotella (Kützing) Brébisson in ancient lakes Ohrid and Prespa and a description of two new species $C$. paraocellata sp. nov. and $C$. prespanensis sp. nov. Nova Hedwigia 98(3-4): 313-340

Cvetkoska A, Levkov Z, Reed JM, Wagner B (2014b) Late glacial to Holocene climate change and human impact in the Mediterranean: the last ca. 17 ka diatom record of Lake Prespa (Macedonia/Albania/Greece). Palaeogeogr Palaeoclimatol Palaeoecol 406:22-32

Damaschke M, Sulpizio R, Zanchetta G, Wagner B, Böhm A, Nowaczyk N, Rethemeyer J, Hilgers A (2013) Tephrostratigraphic studies on a sediment core from Lake Prespa in the Balkans. Clim Past 9:267-287

Fitzsimmons KE, Hambach U, Veres D, Iovita R (2013) The Campanian Ignimbrite Eruption: new data on volcanic ash dispersal and its potential impact on human evolution. PLoS One 8(6):e65839

GICC05modelext (2010). http://www.iceandclimate.nbi.ku.dk/ data/. Accessed 15 Jan 2014

Grimm EC (1987) CONISS: a FORTRAN 77 program for stratigraphically constrained cluster analysis by the method of incremental sum of squares. Comput Geosci 13:13-35

Grimm EC (1991) Tilia and Tilia-Graph. Illinois State Museum, Springfield
Hollis GE, Stevenson AC (1997) The physical basis of the Lake Mikri Prespa systems: geology, climate, hydrology and water quality. Hydrobiologia 351:1-19

Holm NP, Armstrong DE (1981) Role of nutrient limitation and competition in controlling the populations of Asterionella formosa and Microcystis aeruginosa in semicontinuous culture. Limnol Oceanogr 24(4):622-634

Hustedt F (1945) Diatomeen aus Seen und Quellgebieten der Balkan-Halbinsel. Arch Hydrobiol 40:867-973

Jarvis A, Reuter HI, Nelson A, Guevara E (2008) Hole-filled SRTM for the Globe Version 4. Available from: the CGIAR-CSI SRTM 90 m Database. Retrieved 27.11.2011, from http://srtm.csi.cgiar.org

Jones TD, Lawson IT, Reed JM, Wilson GP, Leng MJ, Gierga M, Bernasconi SM, Smittenberg RH, Hajdas I, Bryant CL, Tzedakis PC (2013) Diatom-inferred late Pleistocene and Holocene palaeolimnological changes in the Ioannina basin, northwest Greece. J Paleolimnol 49:185-204

Jongman RHG, ter Braak CJF, van Tongeren OFR (1995) Data analysis in community and landscape ecology. Cambridge University Press, Cambridge, p 324

Juggins S (1991-2007) C2 Version 1.5 User guide. Software for ecological and palaeoecological data analysis and visualization. Newcastle University, Newcastle upon Tyne, UK, p 73

Kilham P, Kilham SS, Hecky RE (1986) Hypothesized resource relationships among African planktonic diatoms. Limnol Oceanogr 31:1169-1181

Krammer K, Lange-Bertalot H (1986-1991) SuËbsswassswasserflora von Mitteleuropa. In: Ettl H, GaËrtner 998 G, Gerloff J, Heynig H, Mollenhauer D (eds) . 2/1: p. 876; 2/2: p. 596; 2/3: 1000 p. 576; 2/4: p. 437; 2/5: Gustav Fischer Verlag, Stuttgart

Krstić S (2012) Environmental changes in Lakes catchments as a trigger for rapid eutrophication-A Prespa Lake Case Study. In: Piacentini T (ed) Studies on environmental and applied geomorphology, pp 63-118. http://www.intechopen.com/ books/studies-on-environmental-and-applied-geomorphology/ geomorphological-changes-in-lakes-catchments-as-a-triggerfor-rapid-eutrophication-a-prespa-lake-cas

Lacey JH, Francke A, Leng MJ, Christopher VH, Wagner B (2014) A high-resolution Late Glacial to Holocene record of environmental change in the Mediterranean from Lake Ohrid (Macedonia/Albania). Int J Earth Sci (Geol Rundsch). doi:10.1007/s00531-014-1033-6

Leng MJ, Baneschi I, Zanchetta G, Jex CN, Wagner B, Vogel H (2010) Late Quaternary palaeoenvironmental reconstruction from Lakes Ohrid and Prespa (Macedonia/Albania border) using stable isotopes. Biogeosciences 7:3109-3122

Leng MJ, Wagner B, Boehm A, Panagiotopoulos K, Vane $\mathrm{CH}$, Snelling A, Haidon C, Woodley E, Vogel H, Zanchetta G, Baneschi I (2013) Understanding past climatic and hydrological variability in the Mediterranean from Lake Prespa sediment isotope and geochemical record over the Last Glacial cycle. Quat Sci Rev 66:123-136

Levin I, Kromer B (2004) The tropospheric ${ }^{14} \mathrm{CO}_{2}$ level in midlatitudes of the Northern Hemisphere (1959-2003). Radiocarbon 46:1261-1272

Levkov Z, Blanco S, Krstic S, Nakov T, Ector L (2007a) Ecology of benthic diatoms from Lake Macro Prespa (Macedonia). Algol Stud 124:71-83 
Levkov Z, Krstic S, Metzeltin D, Nakov T (2007b) Diatoms of Lakes Prespa and Ohrid. About 500 taxa from ancient lake system. Iconographia Diatomologica 16. ARG Gartner Verlag, Ruggell, p 603

Lisiecki LE, Raymo ME (2005) A Pliocene-Pleistocene stack of 57 globally distributed benthic $\delta^{18} \mathrm{O}$ records. Paleoceanography 20:PA1003

Magny M, Joannin S, Galop D, Vanniere B, Haas JN, Basseti M, Bellintani P, Scandolari R, Desmet M (2012) Holocene palaeohydrological changes in the Northern Mediterranean borderlands as reflected by the lake-level record of Lake Ledro, Northeastern Italy. Quat Res 77:382-396

Matzinger A, Spirkovski Z, Patceva S, Wüest A (2006) Sensitivity of ancient Lake Ohrid to local anthropogenic impacts and global warming. J Gt Lakes Res 32:158-179

North Greenland Ice Core Project members (2004) High-resolution record of Northern Hemisphere climate extending into the last interglacial period. Nature 431:147-151

Panagiotopoulos K, Aufgebauer A, Schäbitz F, Wagner B (2013) Vegetation and climate history of the Lake Prespa region since the Lateglacial. Quat Int 293:157-169

Panagiotopoulos K, Böhm A, Leng MJ, Wagner B, Schäbitz F (2014) Climate variability over the last 92 ka in SW Balkans from analysis of sediments from Lake Prespa. Clim Past 10:643-660

R Core Team (2012) R: a language and environment for statistical computing. R Foundation for Statistical Computing, Vienna, Austria. ISBN 3-900051-07-0. http://www.Rproject.org/

Reed JM, Cvetkoska A, Levkov Z, Vogel H, Wagner B (2010) The last glacial-interglacial cycle in Lake Ohrid (Macedonia/Albania): testing diatom response to climate. Biogeosciences 7:3083-3094

Reimer PJ, Baillie MGL, Bard E, Bayliss A, Beck JW, Blackwell PG, Bronk Ramsey C, Buck CE, Burr GS, Edwards RL, Friedrich M, Grootes PM, Guilderson TP, Hajdas I, Heaton TJ, Hogg AG, Hughen KA, Kaiser KF, Kromer B, McCormac FG, Manning SW, Reimer RW, Richards DA, Southon JR, Talamo S, Turney CSM, van der Plicht J, Weyhenmeyer CE (2009) IntCal09 and Marine09 radiocarbon age calibration curves, 0-50,000 years cal BP. Radiocarbon 51:1111-1150

Schmidt R, Kamenik C, Lange-Bertalot H, Klee R (2004) Fragilaria and Staurosira (Bacillariophyceae) from sediment surfaces of 40 lakes in the Austrian Alps in relation to environmental variables, and their potential for palaeoclimatology. J Limnol 63(2):171-189

Smol JP (1988) Paleoclimate proxy data from freshwater arctic diatoms. Verh Int Ver Limnol 23:837-844

Stanković S (1960) The Balkan Lake Ohrid and its living world. Monogr. Biol. IX. Uitgeverij Dr. W. Junk, Den Haag, Netherlands

Vogel H, Zanchetta G, Sulpizio R, Wagner B, Nowaczyk N (2010) A tephrostratigraphic record for the last glacial interglacial cycle from Lake Ohrid, Albania and Macedonia. J Quat Sci 25:320-338

Wagner B, Reicherter K, Daut G, Wessels M, Matzinger A, Schwalb A, Spirkovski Z, Sanxhaku M (2008a) The potential of Lake Ohrid for long-term palaeoenvironmental reconstructions. Palaeogeogr Palaeoclimatol Palaeoecol 259:341-356

Wagner B, Sulpizio R, Zanchetta G, Wulf S, Wessels M, Daut G (2008b) The last 40 ka tephrostratigraphic record of Lake Ohrid, Albania and Macedonia: a very distal archive for ash dispersal from Italian volcanoes. J Volcanol Geoth Res 177:71-80

Wagner B, Lotter AF, Nowaczyk N, Reed JM, Schwalb A, Sulpizio R, Valsecchi V, Wessels M, Zanchetta G (2009) A 40.000-year record of environmental change from ancient Lake Ohrid (Albania and Macedonia). J Paleolimnol 41: 407-430

Wagner B, Vogel H, Zanchetta G, Sulpizio R (2010) Environmental changes on the Balkans recorded in the sediments from lakes Prespa and Ohrid. Biogeosciences 7:3365-3392

Wagner B, Aufgebauer A, Vogel H, Zanchetta G, Sulpizio R, Damaschke M (2012) Late Pleistocene and Holocene contourite drift in Lake Prespa Albania/F.Y.R. of Macedonia/Greece. Quat Int 274:112-121

Wagner B, Leng MJ, Wilke T, Böhm A, Panagiotopoulos K, Vogel H, Lacey JH, Zanchetta G, Sulpizio R (2014a) Distinct lake level lowstand in Lake Prespa (SE Europe) at the time of the 74 (75) ka Toba eruption. Clim Past 10:261-267

Wagner B, Wilke T, Krastel S, Zanchetta G, Sulpizio K, Reicherter K, Leng M, Grazhdani A, Trajanovski S, Levkov Z, Reed J, Wonik T (2014b) More than one million years of history in Lake Ohrid cores. Eos Trans Am Geophys Union 95(3):25-26

Wagner B, Wilke T, Krastel S, Zanchetta G, Sulpizio R, Reicherter K, Leng MJ, Grazhdani A, Trajanovski S, Francke A, Lindhorst K, Levkov Z, Cvetkoska A, Reed JM, Zhang X, Lacey JH, Wonik T, Baumgarten H, Vogel H (2014c) The SCOPSCO drilling project recovers more than 1.2 million years history from Lake Ohrid. Sci Drill 17:19-29

Wilson GP, Reed JM, Lawson IT, Frogley MR, Preece RC, Tzedakis PC (2008) Diatom response to the last glacial interglacial transition in the Ioannina basin, northwest Greece: implications for Mediterranean palaeoclimate reconstruction. Quat Sci Rev 27:428-440

Wilson GP, Frogley MR, Roucoux KH, Jones TD, Leng MJ, Lawson IT, Hughes PD (2013) Limnetic and terrestrial responses to climate change during the onset of the penultimate glacial stage in NW Greece. Glob Planet Change 107:213-225

Wolff EW, Chappellaz J, Blunier T, Rasmussen SO, Svensson A (2010) Millennial-scale variability during the last glacial: the ice core record. Quat Sci Rev 29:2828-2838 